
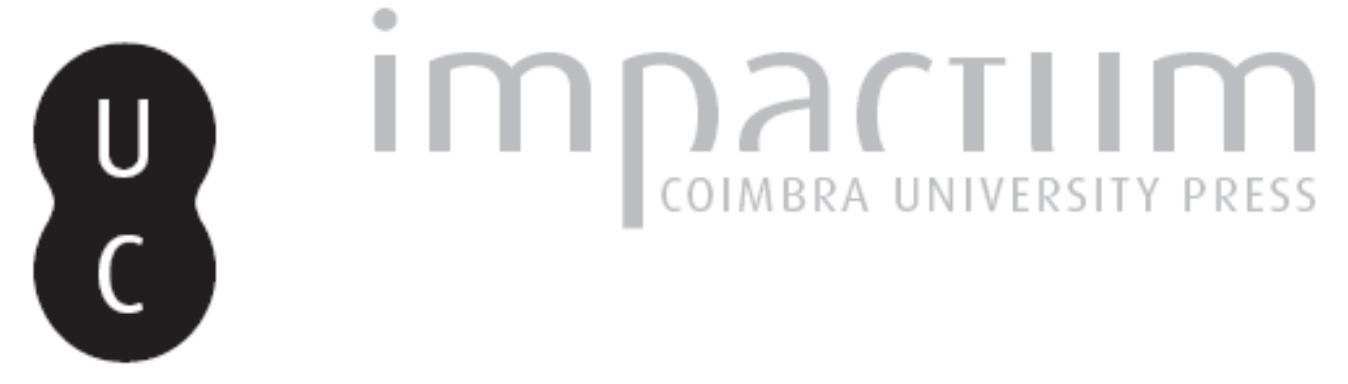

Eduardo Kac e o oitavo dia: reflexões sobre uma ecologia transgénica

Autor(es): $\quad$ Valente, Pedro

Publicado por: CIAS - Centro de Investigação em Antropologia e Saúde

URL persistente:

URI:http://hdl.handle.net/10316.2/28690

DOI:

DOI:http://dx.doi.org/10.14195/2182-7982_27_10

Accessed : $\quad$ 26-Apr-2023 15:35:16

A navegação consulta e descarregamento dos títulos inseridos nas Bibliotecas Digitais UC Digitalis, UC Pombalina e UC Impactum, pressupõem a aceitação plena e sem reservas dos Termos e Condições de Uso destas Bibliotecas Digitais, disponíveis em https://digitalis.uc.pt/pt-pt/termos.

Conforme exposto nos referidos Termos e Condições de Uso, o descarregamento de títulos de acesso restrito requer uma licença válida de autorização devendo o utilizador aceder ao(s) documento(s) a partir de um endereço de IP da instituição detentora da supramencionada licença.

Ao utilizador é apenas permitido o descarregamento para uso pessoal, pelo que o emprego do(s) título(s) descarregado(s) para outro fim, designadamente comercial, carece de autorização do respetivo autor ou editor da obra.

Na medida em que todas as obras da UC Digitalis se encontram protegidas pelo Código do Direito de Autor e Direitos Conexos e demais legislação aplicável, toda a cópia, parcial ou total, deste documento, nos casos em que é legalmente admitida, deverá conter ou fazer-se acompanhar por este aviso.

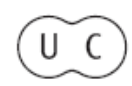




\section{Antropologia Portuguesa}

Volume $26-27 \cdot 2009-2010$

Departamento de Antropologia | Universidade de Coimbra

DARWINISMO:

revisitações, propostas, problemas 


\title{
Eduardo Kac e o Oitavo Dia: Reflexões sobre uma ecologia transgénica
}

\author{
Pedro Valente \\ Faculdade de Direito \\ Universidade de Coimbra, Portugal \\ pmvalente@gmail.com
}

Resumo $\mathrm{O}$ artigo que seguidamente se apresenta estuda uma obra realizada através das novas práticas artísticas que resultam das relações de cooperação que se têm verificado recentemente entre os domínios da arte e da tecno-ciência e a que se convencionou chamar "bio-arte". Tendo em conta as criações que daí resultam, particularmente as que recorrem à engenharia genética, o cenário apresentado poderá parecer alarmante, mas a realidade revela-se diferente. Assim, ao longo do trabalho efectuado, após análise das formas de intervenção da bio-arte, verificou-se que elas são eminentemente de carácter social, questionando criticamente os avanços da ciência contemporânea, e revestindo-se de enormes preocupações éticas, não alarmando, mas alertando o público para as questões dos nossos dias.

Palavras-chave Bio-arte; arte transgénica; biotecnologia; ética; ecologia.

Abstract The following work studies the new artistic practices that result from the cooperation that has been made recently between the fields of art and technoscience, which is called "bio-art". Given the works that are created, particularly those that rely on genetic engineering, the scenario may seem alarming, but the reality has proved to be different. In the course of this investigation, some works of bio-art have been analyzed, and was found that they have an important social nature, critically questioning the progress of contemporary science, and wondering about their ethical concerns, alerting the public to the issues of our times.

Key Words Bio-art; transgenic-art; biotechnology; ethics; ecology.

"Com O Oitavo Dia eu chamo a atenção para o facto de uma ecologia transgénica já estar instalada." (Kac, 2005: 288)

\section{Introdução}

Os 151 anos passados desde a publicação de A Origem das Espécies de Charles Darwin, além de uma boa oportunidade para nos levar a reflectir 
sobre a forma como uma teoria científica revolucionou a nossa percepção da Humanidade ao longo deste último século e meio, são também um momento ímpar para nos interpelarmos sobre o que nos reserva o futuro, particularmente no campo da Biologia, onde o Darwinismo teve o seu expoente máximo como ferramenta explicativa.

Deste modo, é importante estar atento à arte, que nos pode ajudar a desvendar novos caminhos, auxiliando-nos na projecção de um futuro, repleto de incertezas, dúvidas, receios.

Entendeu-se por isso abordar neste trabalho a chamada bio-arte, que resumidamente se pode caracterizar como uma nova forma de arte inspirada na Biologia e que faz uso de metodologias laboratoriais de experimentação. $\mathrm{Na}$ bio-arte coexistem várias abordagens. Algumas derivam da vida e da inteligência artificial, outras da robótica, da genética, dos mais recentes desenvolvimentos das teorias da complexidade, da biotecnologia, etc. Uma das particularidades da bio-arte reside no facto da inspiração que esta vai buscar às ciências naturais não ser meramente representativa, estática $\mathrm{e}$ contemplativa. Ela é inspirada nos processos evolutivos, nas novas descobertas científicas e nas discussões que se podem desenrolar a partir dos novos conceitos e formas de perspectivar o mundo e os seres vivos, nomeadamente o ser humano.

Assim, através de uma obra exemplificativa da arte transgénica, $O$ Oitavo Dia, de Eduardo Kac, é objectivo deste texto analisar as dinâmicas produzidas pelo trabalho do artista, de modo a compreender as suas implicações nos sujeitos que se encontram em interacção. Seguro de que este tipo de ecossistemas transgénicos encerra muitas questões que poderão convocar as teorias de Darwin, entre muitas outras, este contributo privilegiará a ideia de evolução enquanto sistema de comunicação entre seres.

Será, então, interessante abordar o percurso criativo deste artista.

\section{Eduardo Kac}

Eduardo Kac é um artista basilar para compreender o fenómeno da bio-arte, já que a sua obra trata essencialmente da discussão que envolve os últimos avanços tecnológicos. Este artista tem como preocupação colocar em ênfase assuntos controversos como a manipulação genética e o uso das tecnologias na nossa sociedade, ajudando a compreender as novas possibilidades estéticas na aproximação entre a ciência e a arte. 
O primeiro trabalho de telepresença de Kac é de 1997. Em Rara Avis, uma ave-robô é colocada numa gaiola com outros pássaros e ao visitante é dada a possibilidade de trocar de lugar com a ave, ficando este engaiolado com as demais aves. Em Darker than Night (1999), o visitante troca de lugar com um robô-morcego que estava entre cerca de 300 morcegos frutívoros. O robô-morcego possuía um sonar na cabeça e as imagens eram transmitidas em tempo real para óculos de realidade virtual. Nesses dois trabalhos fica clara a preocupação de Kac para com a troca de papéis. Outro ponto interessante é apresentar a visão que outro animal faz do mundo, o que contribui para a valorização das outras formas de vida, assunto crucial das discussões do pós-humanismo.

Um outro trabalho que mostra essa preocupação é Teleporting an Unkown State (1996). Nesta obra, o crescimento de uma planta é monitorizado por câmaras podendo os visitantes controlar a sua taxa de crescimento, enviando luz por um interface na web. Neste caso, o processo biológico - nascimento e crescimento da planta - é parte constitutiva do trabalho e só é possibilitado a partir da interacção dos espectadores. A acção de indivíduos espalhados pelo globo terrestre torna possível o crescimento de um organismo vivo (não virtual), dando a estes indivíduos um sentimento de responsabilidade colectiva (Cruz, 2004: 89).

Desde as primeiras experiências feitas por Eduardo Kac do que ele apelidou de "arte transgénica", o que se apresenta é uma reflexão sobre as consequências da transformação sociocultural promovida pelas discussões éticas dos desdobramentos das novas descobertas científicas.

Kac admite que apesar de todas as obras de arte terem de lidar com questões éticas, estas tornam-se mais cruciais do que nunca no contexto da bio-arte, campo ainda muito mal compreendido pelo grande público, que assiste ao debate dos avanços da biotecnologia a partir do sensacionalismo da imprensa e de eventos como o nascimento da ovelha Dolly (Pisaneschi, 2006: 7). Assim, a polémica levantada pela comunicação social criou uma enorme confusão entre a opinião pública relativamente aos conceitos técnicos das biotecnologias, como é o caso de "clone" e "transgénico".

Como questiona Luís Quintais (2007: 93); “Será a performance de Ian Wilmut quando apresentou ao mundo a ovelha Dolly (1997) menos perigosa do que a performance de Kac quando apresentou a sua Alba?"

Em Time-Capsule (1997), no primeiro projecto de Kac usando o conceito de moist media, o artista parte dos pressupostos de que a pele já deixou 
de ser a barreira imutável que contém e define o corpo no espaço (Cruz, 2004: 92), e de que, mais do que tornar visível o invisível, a arte deve possibilitar a consciência do que permanece para além do visual, mas que de facto nos afecta directamente. A inserção do micro-chip no tornozelo tem um sentido simbólico evidente, por ser uma área do corpo que tradicionalmente foi acorrentada ou marcada. Através dessa experiência, Kac coloca em debate tanto o problema ético relativo à sociedade de controlo em que vivemos, assim como o futuro da espécie humana a partir do momento em que se torna possível a inserção de memória digital no nosso organismo vivo. Os sistemas de controlo estão cada vez mais sofisticados e a biométrica surge como mais uma ferramenta de controlo tão poderosa que nos faz lembrar narrativas de ficção científica. O tempo é outra questão central neste trabalho, já que a experiência se desenrola entre o efémero - o tempo necessário para a implantação do chip - e o permanente - todo o tempo que o chip ficará sob a pele do artista (Pisaneschi, 2006: 8).

Em A-Positive (1997), com a colaboração de Ed Bennet, Kac promove uma troca intravenosa entre um robô e um homem através de tubos que transmitiam o sangue de um para o outro. O bio-robô extraía oxigénio do sangue que recebia e mantinha uma chama acesa, devolvendo posteriormente glicose ao ser humano. Ao nutrir o robô com sangue humano, cria-se uma simbiose máquina-humano que inverte a relação hierárquica que normalmente rege as relações entre seres vivos e máquinas. A única "função" do bio-robô é simbólica, através da criação da metáfora da vida a partir da pequena chama que se mantém acesa com o oxigénio retirado da hemoglobina do sangue do artista.

Kac procura levar o grande público a reflectir sobre as consequências do desenvolvimento da biotecnologia, criando um diálogo entre ciências exactas e humanas através da arte.

A ponte entre estas "duas culturas" estabelecida pelos artistas interessados nas novas tecnologias será o caminho para a criação de uma nova cultura. No entanto, é importante ressaltar, como fez Michel Punt, que não se dá o caso dos artistas passarem a "fazer ciência" ou vice-versa.

"A corrosão dos limites nas artes, por exemplo, ensejou novas combinações de sistemas de crença e práticas, à medida que a diferença entre o artista e o cientista aparentemente se dissolveu. Isso, todavia, não deve ser confundido com a ideia de que os artistas, de algum modo mágico, estariam 
"a fazer ciência" e vice-versa. Essa solubilidade não é consequência das mudanças na arte e na ciência, mas antes de uma forma emergente de consciência que compreende a si mesma como cúmplice nas histórias e ilusões necessárias para organizar dados." (Punt, 2003: 314).

Como em Genesis, GFP Bunny e O Oitavo Dia, o conceito de autoria (tanto artística, como divina) é colocado em questão. Além da obra ser assinada não apenas por Kac, mas também por uma equipa transdisciplinar, a participação do público através da Internet e o imprevisível comportamento dos seres vivos que constituem a obra fazem com que esta tenha um desenvolvimento próprio independente de qualquer projecção a priori do artista ou dos cientistas que a criaram. A obra de arte adquire vida própria, evidenciando a sua condição de "sistema vivo" (Pisaneschi, 2006: 9).

GFP Bunny (2000) foi um trabalho que teve amplo destaque na comunicação social devido à enorme polémica que gerou. Através de engenharia genética, foi criada uma coelha com GFP (Green Fluorescent Protein), de seu nome Alba. Sob luz azul, a coelha emite luz verde. A obra foi dividida em três fases: a criação da coelha, a convivência dela numa casa (o objectivo de Kac era levá-la para morar com a sua família, o que não foi possível) e na última fase a discussão que esse processo iria gerar (Kac, 2005: 266).

Este trabalho não foi polémico apenas para o público que ficou confuso com as informações divulgadas. Até mesmo o cientista que criou Alba realizou várias críticas ao trabalho de Kac (Philipkoski, 2002). O início do desentendimento entre Kac e Louis-Marie Houdebine surgiu com a fotografia de Alba publicada no jornal Boston Globe a 17 de Setembro de 2000. A fotografia mostrava Alba totalmente verde, tendo o geneticista ficado preocupado com a imprecisão científica que esta transmitia. Isto porque a coelha só pode expressar o gene nas partes de tecido vivo (pele), de modo que a fotografia que mostrava o seu pêlo esverdeado não poderia ser real. Trata-se portanto de um artefacto fotográfico ou de uma manipulação consciente da imagem. Houdebine resolveu afastar-se do projecto e esfriou a sua relação com Kac receando que informações erróneas pudessem confundir ainda mais o público em geral sobre os transgénicos. O investigador também contesta a informação de Kac de que Alba tenha sido criada especificamente para ele, afirmando que jamais criaria um animal para qualquer artista. Segundo Houdebine, Alba foi escolhida entre os animais do laboratório pois era a mais dócil (Pisaneschi, 2006: 10). 
O trabalho de Kac ficaria no entanto incompleto, pois Alba nunca pôde ir morar com a família do artista, que era o seu objectivo inicial (Kac, 2005: 266). De qualquer modo, conseguiu gerar inúmeras discussões sobre a criação de um animal transgénico.

Já em 2001 Kac cria O Oitavo Dia, um verdadeiro ecossistema de seres transgénicos verdes (ratos, peixes, plantas e amebas), todos criados com GFP. A obra, que se ligava à Internet de várias formas, incluía um robô biológico, que possuía um cérebro de amebas GFP.

\section{O Oitavo Dia}

Importa agora fazer uma análise com maior detalhe sobre $O$ Oitavo Dia. Este é bem representativo daquilo que está em questão quando falamos de arte transgénica. Apesar de não ter tido tanto impacto mediático como GFP Bunny, algumas das questões que o autor pretendia abordar através da convivência de Alba no seu meio familiar, nomeadamente a relação com seres transgénicos e a responsabilidade que daí advém, estão bem patentes neste ecossistema transgénico.

Um bom caminho para melhor compreender esta obra é olhar para ela enquanto uma forma de comunicação entre sujeitos, tal como Eduardo Kac a pensou.

O Oitavo Dia foi desenvolvido pelo artista e por uma vasta equipa de artistas, cientistas e especialistas em tecnologia no Institute for Studies in the Arts, na Arizona State University, na qual foi exposta em 2001. A obra reorganiza a relação simbiótica entre diferentes entidades, tais como os humanos e as amebas. Trata-se de um projecto artístico que discute questões de ética e responsabilidade a partir das relações existentes entre os humanos e os transgénicos e dos próprios transgénicos entre si.

Esta criação mostra uma população de seres fluorescentes criados em laboratório, que, quando em conjunto, sugerem o núcleo de um sistema sintético bioluminescente. Segundo o artista (Kac, 2005: 286), O Oitavo Dia convida o participante a "caminhar sobre a água". O participante da instalação entra inicialmente em contacto com uma semi-esfera azul. Trata-se de uma cúpula em Plexiglas de 1,25 $\mathrm{m}$ de diâmetro com uma luz interna, $\mathrm{o}$ que provoca um efeito visual incandescente. Além disso, o visitante ouve sons recorrentes de água a fluir para a praia, o que evoca a imagem da Terra vista do Espaço. Para Eduardo Kac, os sons funcionam como uma "metáfora 
da vida na Terra, reforçada pela imagem azul esférica, que ressoa com o vídeo da água projectada no solo" (Kac, 2005: 286).

Relativamente ao nome da instalação, O Oitavo Dia, trata-se de uma referência directa à história da criação, do ponto de vista bíblico. Dado que segundo a cultura Judaico-Cristã foi no sétimo dia que Deus criou o ser humano. Assim, o dia seguinte é então proposto por Kac como o da criação de uma nova ecologia, um mundo onde humanos se relacionam com criaturas modificadas geneticamente em laboratórios. Daí a "metáfora da vida na Terra" representada pela comunicação dialógica entre seres humanos e seres tecnológicos que co-habitam um espaço único.

Neste projecto, "a vida" é evocada pela presença de um robô e de seres transgénicos que se relacionam dentro do globo. Quanto à base tecnológica dos transgénicos, esta é manifestada pela coloração verde que adquirem sob iluminação especial. A esse mundo é acrescentada a espécie humana representada tanto pelos visitantes que, na galeria, passam a conviver com os seres transgénicos, assim como pelos visitantes remotos que interferem no ecossistema através da Internet.

Deste modo, o contacto do participante com o "outro" (os seres transgénicos) tem lugar sob o olhar da ética e da responsabilidade para com esses sujeitos tecnológicos. Assim, a "metáfora da vida" é explicada pela comunicação existente entre os humanos e os seres tecnológicos, tendo por meio os dispositivos comunicacionais que permitem uma relação dialógica entre eles. Nessa perspectiva, fica evidente a constituição de uma sofisticada metáfora ou alegoria sobre a conexão, a comunicação e a interacção entre os diversos seres, sejam eles plantas, animais ou máquina(s). O próprio autor acredita que a comunicação entre os seres se dá não só pela troca de palavras, símbolos ou gestos, mas também pela comunicação não-semiótica que ocorre por meio dessa transposição do indivíduo para uma realidade virtual (Kac, 2005: 292).

Quanto aos seres que habitam este sistema ecológico artificial, eles foram escolhidos com vista a representarem os vários reinos ${ }^{1}$. Deste modo, estão presentes na obra espécies de plantas, $a_{m e b a s}^{2}$, peixes e ratos vivos, expressando todos a proteína fluorescente verde (GFP) com a bioluminescên-

\footnotetext{
${ }^{1}$ Para uma melhor explicação sobre o actual sistema taxonómico consultar http:// en.wikipedia.org/wiki/Kingdom_(biology).

${ }^{2} \mathrm{~A}$ ameba (Dyctiostelium discoideum) também é conhecida como bolor de lodo.
} 
cia visível a olho nu. O gene GFP, próprio de um tipo de medusa (Aequorea victoria), quando fixado em células procarióticas ou eucarióticas, produz uma fluorescência verde após a excitação das células por luz azul ou UV. Para além do seu uso criativo, como em O Oitavo Dia e GFP Bunny, o GFP é sobretudo utilizado em vários campos da Biologia, tais como a Microbiologia, a Engenharia Genética e a Fisiologia. O gene que codifica esta proteína já foi isolado e é actualmente utilizado na produção de proteínas de fusão, constituídas por um gene de interesse ${ }^{3}$ fundido com o da GFP, de modo a monitorizar, por exemplo, a localização dessa proteína in vivo.

Mas nem só de seres transgénicos vive a instalação. Faz também parte da obra um bio-robô, conceito este introduzido por Eduardo Kac no catálogo do ISEA'97, definindo-o como "um robô com um elemento biológico activo no seu corpo, responsável por aspectos do seu comportamento" (apud Silva, 2007). Esse elemento biológico é uma colónia de amebas GFP que exercem a função de cerebelo do bio-robô. Quando as amebas se reproduzem ou se movimentam, o bio-robô mexe-se lentamente, para cima e para baixo, deslocando-se, assim, pela galeria, nos momentos de actividade, ascendentemente, e nos de repouso, de forma descendente. O robô, que se encontra pousado sobre seis pernas robóticas articuladas, é um objecto instável, com uma superfície que guarda componentes electrónicos. Entre as suas muitas características estão duas pequenas câmaras de vídeo e um "cérebro" constituído pela referida população de amebas numa caixa de Petri iluminada. Uma outra câmara de vídeo minúscula está montada directamente acima das amebas, podendo ser focada por um mecanismo de precisão, a outra está num braço giratório no topo do bio-robô (Collins, 2003).

Dan Collins, uma das colaboradoras de Kac nesta iniciativa explica que a ideia da obra era que o robô se aproveitasse do movimento das amebas. No interior do bio-reactor transparente, as amebas formam uma rede cujo comportamento é determinado pelas respostas aos estímulos ambientais. Assim, as amebas constituem o "sistema nervoso" do bio-robô, juntamente com uma unidade sensorial interna e um computador. Como explica o próprio autor, "a unidade sensorial interna é responsável pelo rastreio do movimento das amebas e o computador emite comandos para as pernas do bio-robô, em

${ }^{3}$ Um gene de interesse (também conhecido por transgene) é um gene ou material genético que tenha sido transferido por meio de uma técnica de engenharia genética de um organismo para outro. 
resposta a tal movimento" (Kac, 2005: 290). Desta forma, cada movimento realizado pelo bio-robô, é um sinal visual de actividade por parte das amebas.

Além destas funcionalidades, o bio-robô é também o avatar dos utilizadores remotos, que através da Internet são transportados para o interior do ambiente. Independentemente do movimento que o robô faça, o participante virtual pode controlar o seu olho, ao girá-lo 360 graus ao redor do seu corpo. Assim, os movimentos de avanço e recuo que resultam da acção das amebas em combinação com o sistema electrónico do robô possibilitam que o utilizador tenha uma nova perspectiva do ambiente.

Como explica Kac (2005: 290):

"O comportamento global do bio-robô é uma combinação da actividade que ocorre na rede microscópica das amebas e na rede humana macroscópica. Humanos e amebas "encontram-se" no corpo do bio-robô e afectam mutuamente as suas experiências e comportamentos, produzindo, pela sua ligação, um "domínio consensual" efémero".

Deste modo, o ser humano é o último elemento que compõe o novo ecossistema, participando na obra tanto pela sua presença na instalação como pela Internet, transportando-se para o interior do terrarium.

Falou-se até aqui de comunicação e relação entre as várias espécies que compõem a obra, o público que a visita e que ao mesmo tempo é emerso na mesma, na medida em que ele passa a fazer parte do ecossistema. Mas importa falar também da relação, essa estritamente entre humanos, que ocorreu entre as pessoas que trabalharam na sua produção para que ela fosse exibida.

Assim, para que todos os componentes que integram a obra fossem desenvolvidos, como a cúpula, o bio-robô, os programas de computador e as câmaras, foi necessário encontrar vários colaboradores. Deste modo, Kac foi buscar ao Departamento de Biologia da Arizona State University (ASU) a participação dos geneticistas Alan Rawls e Jeanne Wilson-Rawls, que forneceram a informação para o desenvolvimento do ambiente que os seres vivos transgénicos iriam habitar. Além disso, procurou a contribuição

\footnotetext{
${ }^{4}$ Como explica Kac, um "domínio consensual” não implica consenso; significa antes consensualidade, coincidência sensorial que, em organismos mais complexos pode, por extensão, implicar também interacção cognitiva (Kac, 2005: 294).
} 
do Institute for Studies in the Arts (ISA), também da ASU. Como contam Collins e Britton (apud Silva, 2007), que também colaboraram neste projecto, os trabalhos de equipa tiveram início em Janeiro, tendo sido intensificados semanalmente a partir de Junho até à data da primeira exibição em Outubro de 2001. David Loring, director técnico especialista em escultura e teatro, projectou e fabricou o bio-robô, baseado num projecto 3D idealizado pelo seu assistente, James Stewart. George Pawl e Kelly Phillips, também directores técnicos com experiência em instalações em museus e teatros desenharam e fabricaram a cúpula com o auxílio de estudantes de pós-graduação. Ozzie Kidané, engenheiro do ISA, desenvolveu o hardware de controlo do biorobô. Gene Cooper, artista de novos media, contribuiu no projecto tanto pelo desenvolvimento das câmaras virtuais para a instalação como do website de O Oitavo Dia. Grant Orvis, do Departamento de Biologia da ASU, além de auxiliar os trabalhos dos geneticistas durante todo o projecto, guardava também os exemplares de vida para a exibição. Participaram ainda: Richard Loveless, Dan Collins, Sheilah Britton, Barbara Eschbach, Julia Friedman, Isa Gordon, Charles Kazilek e Frances Salas (Silva, 2007).

Apesar de poder parecer algo desnecessário enumerar aqui os colaboradores de Kac no projecto, cuidado que de resto o artista tem (Kac, 2005: 293), é importante ter presente todas as pessoas que levaram a cabo esta obra. Por aí podemos constatar a diversidade de pessoas envolvidas, das mais variadas áreas, com funções e formações muito diferentes, que se mobilizaram em torno de um objectivo e através da comunicação conseguiram realizá-lo com êxito. Quase se pode imaginar a riqueza dos diálogos multidisciplinares entre os participantes, as diferentes perspectivas e trocas de ideias sobre o tema no qual trabalharam. Provavelmente não haverá uma área que se constitua como um campo tão interessante para colocar em jogo as diversas opiniões e mobilizar pessoas de quadrantes tão diferentes. E a arte tem esse mérito, de colocar as pessoas em contacto a debater ideias e posteriormente materializar esse trabalho reflexivo em algo tangível passível de ser transportado para o espaço público, para que a comunidade também as discuta e encontre assim o(s) caminho(s), que mais se adequa(m) aos seus anseios e aspirações.

Neste caso, "interessa a arte (não) final" (Silva, 2007). Por um lado, final porque é o resultado do trabalho de colaboração da equipa, mas ao mesmo tempo não final, na medida em que $O$ Oitavo Dia não se apresenta como uma obra acabada. Ela só existe realmente no aqui e no agora, a par- 
tir da acção do ser humano em interacção com todos os outros seres que a integram. E mesmo assim, ela apresenta-se a cada instante de uma forma distinta, já que as entidades nela presentes estão em constante locomoção. Segundo Silva (2007), "O Oitavo Dia desenvolve um modelo de comunicação dialógico, que incorpora a subjectividade dos individuos como factor fundamental da obra. "Essa comunicação é feita pela interacção entre uma ou mais entidades vivas no sentido biológico. Na obra, o processo comunicacional é mediado pela telepresença, sendo o elo o bio-robô, que funciona como um interface para a participação pela Internet, transportando o sujeito para o interior do ambiente. O participante explora assim à distância, em tempo real, via Internet, o espaço no qual está o robô, determinando as amebas o seu movimento. Quando elas se deslocam em direcção a uma das seis pernas do bio-robô, essa perna contrai-se, enquanto a outra volta à posição original. Assim, como foi referido anteriormente, os utilizadores, independentemente do movimento que o robô faça, podem controlar o seu olho (Kac, 2005: 290). No entanto, o comportamento dinâmico e imprevisível do bio-robô fornece aos participantes remotos uma perspectiva do ambiente nova, na medida em que estes não a conseguem controlar completamente.

Assim, compreende-se que a existência da obra dependa da sua interacção com o utilizador, aquele que a usa em tempo real. Podendo os participantes interferir no processo ao ocupar o ponto de vista do bio-robô. É seguramente um caso paradigmático do tão caro à Antropologia "Native `s point of view".

Se considerarmos o ponto de vista do participante remoto, verificamos que o humano já desde o início se torna um ser híbrido, na medida em que se misturam os componentes do humano, da máquina e do transgénico. Mesmo tomando o ponto de vista do bio-robô, nem as amebas, nem os seres humanos têm total controlo sobre ele, já que este se converte num lugar de interacção entre organismos e utilizadores. O que se estabelece é uma conexão entre o físico e o virtual, entre o biológico e o tecnológico, rompendo as fronteiras entre os seres, desenvolvendo assim uma nova ecologia. Desta forma, o artista coloca em evidência a interacção entre a máquina e os seres vivos, permitindo que coexistam elementos do espaço virtual e do real, procurando expandir o corpo através do electrónico e da tele-acção (Silva, 2007). Área esta que já vinha a ser trabalhada por Kac em projectos anteriores, como os já mencionados Rara Avis, Darker than Night e Teleporting an Unkown State. 
Dan Collins (2003) explica que a instalação possui quatro câmaras posicionadas para dentro e para fora da cúpula. Duas delas, uma montada sobre o eixo central do braço do robô e outra no topo da instalação, dão a opção ao utilizador de interagir com a obra através de mecanismos pan e zoom em tempo real. Outra câmara encontra-se localizada na caixa de Petri e a restante nos sons produzidos pela faixa de água e em contacto com os peixes e plantas. Assim, o visitante pode estabelecer vários eixos de visão dependendo da posição que escolha. Segundo Collins, ele pode interagir com a obra observando "o olho de Deus a partir de cima; um olho de peixe literal adjacente à lagoa; a visão de um micróbio das amebas; e uma perspectiva peripatética sempre em movimento ao girar em torno do bio-robô." (Collins, 2003). O visitante remoto também pode ver os próprios humanos confinados à instalação em redor da cúpula.

Desta forma, o visitante remoto que se encontra ligado à Internet vê o espaço do ponto de vista do bio-robô, podendo olhar para o exterior da cúpula, e perceber os rostos e os corpos dos participantes locais do ambiente transgénico. Observando assim os visitantes locais como parte integrante da ecologia do projecto, como se humanos e transgénicos co-existissem simbolicamente numa "Internet-esfera". No entanto, os visitantes locais podem demorar algum tempo a perceber esta dinâmica.

Como refere Kac (2005: 292):

"Os visitantes locais podem acreditar temporariamente que o seu olhar é o único olhar humano a contemplar os organismos da cúpula. No entanto, quando navegam no interface da Internet percebem que espectadores remotos também podem experimentar o ambiente do ponto de vista do olho de um pássaro, visualizando-o, de alto a baixo, através de uma câmara instalada sobre a cúpula. É possivel fazer movimentos de pan, tilt e zoom, vendo de mais longe ou mais perto, humanos, ratos, plantas, peixes e o bio-robô."

Assim, apenas através do computador on-line instalado na galeria é que os visitantes locais percebem o sentido da experiência. Segundo Collins (2003), os múltiplos pontos de acesso à obra e as suas alusões, que se deslocam entre os campos da arte e da ciência, têm como missão posicionar o utilizador entre dois pólos distintos, mas ao mesmo tempo entrecruzáveis: alegoria e percepção, actos e interpretação e experiências sensoriais.

Como diz Kac (2005: 292): 
"Ao permitir aos participantes experimentar o ambiente dentro da cúpula do ponto de vista do bio-robô, O Oitavo Dia cria um contexto no qual os participantes podem reflectir sobre o significado de uma ecologia transgénica a partir de uma perspectiva na primeira pessoa."

Verifica-se assim que para Eduardo Kac, com O Oitavo Dia, a ecologia transgénica já se encontra instalada (Kac, 2005: 288). A obra como uma importante "metáfora da vida na Terra" leva-nos a uma reflexão mais profunda a respeito do uso da vigilância e de técnicas de controlo sobre o mundo natural. A cápsula que envolve a fauna e a flora fluorescentes permite que relacionamentos até então invisíveis na natureza possam ocorrer. $\mathrm{O}$ conceito de dominação do ser humano sobre a natureza foi herdado do discurso bíblico, que promete o controlo dos humanos, não deixando legado para os restantes animais. Assim, O Oitavo Dia parece transgredir esse discurso, já que ao apresentar seres transgénicos "exóticos”, convida-nos à abertura para "essa variedade infinita de imagens e formas de vida estranhas - medos, sonhos e invenções - que assombram a nossa imaginação colectiva” (Collins, 2003). Pretendendo Kac, com a sua arte transgénica, realizar um trabalho "no qual as noções românticas daquilo que é 'natural'sejam questionadas e que o papel humano na história evolutiva das outras espécies (e vice-versa) seja reconhecido, enquanto este fenómeno surpreendente a que chamamos "vida" seja admirado de forma respeitosa e humilde." (Kac, 2005: 292-293).

Assim, ao efectivar a comunicação entre as diversas entidades que integram a obra, Kac coloca em evidência a necessidade de reflectir sobre a diferença entre o animal e o humano. Isto porque a filosofia acerca dessa relação exalta sobretudo a superioridade e subjugação do animal relativamente ao humano. Para Kac, o interessante seria desfazer essa polaridade, ao estabelecer uma ambiguidade e uma subjectividade para a comunicação entre esses seres. Segundo Britton e Collins (apud Silva, 2007) "Kac acredita similarmente que os artistas podem oferecer importantes alternativas para o debate polarizado sobre engenharia genética, colocando 'ambiguidade e subjectividade 'no lugar da polaridade”.

Ao seleccionar e desenvolver seres transgénicos especificamente para o projecto artístico, o autor está a propor uma reflexão sobre essa evolução transgénica e também sobre o modo como ela afecta o ser humano na sua relação com os outros seres. Para o próprio autor, a obra mostra que a con- 
vivência (tangível e simbólica) entre humanos e transgénicos revela novos caminhos na evolução da relação dos humanos com as outras espécies. Chamando a atenção para a necessidade de se desenvolverem novos modelos que tornem possível entender essa mudança, assim como de interrogar a diferença, levando em conta clones, transgénicos e quimeras (Kac, 2005: 292).

É de recordar que o ser humano selecciona e faz cruzamentos que geram híbridos desde a antiguidade, criando novas espécies desses cruzamentos. Neste aspecto a discussão de Kac é importante para mostrar por meio da luminescência a alteração que os humanos produzem. Muitas vezes uma pequena modificação morfológica ou anatómica pode passar despercebida por gerações, mas a luminescência "ilumina" a nossa percepção das alterações, que embora de forma subtil, estão presentes (Pisaneschi, 2006: 10).

A criação destes seres dá à obra um carácter reflexivo em questões como a ética e a estética, elementos indissociáveis. Numa entrevista publicada originalmente no jornal Folha de São Paulo, Eduardo Kac explicou que a sua preocupação estética é a de "inventar novos sujeitos sociais. Criar seres com características fisicas sim, como a coloração, mas também mentais e emotivas". Acrescentando ainda que "A invenção de uma vida leva a uma confrontação. Ai está a dimensão ética." (Machado, 2002). Como dizia o artista a propósito da sua obra mais famosa:

“Alba não é um protótipo nem um "hype". É um ser vivo que obriga a pensar nos elementos éticos e afetivos das relações que emergem com a engenharia genética." (Beiguelman, 2002).

No entanto, enquanto falamos de seres transgénicos, a nossa imaginação torna-se extremamente fértil sem contudo se lembrar na possibilidade de nós mesmos sermos considerados como tal.

Parece algo confuso, mas como argumenta Kac, o Projecto Genoma Humano deixou claro que todos os seres humanos possuem no seu genoma sequências oriundas de vírus que foram sendo adquiridas ao longo da história da evolução, o que mostra que temos nos nossos corpos ADN de organismos não-humanos. Logo, isso significa que também nós somos transgénicos (Kac, 2005: 292).

Assim, um dos aspectos para que o trabalho de Kac chama a atenção é precisamente o da utilização crescente da técnica de transgenia, particularmente a questão da evolução transgénica. E de facto assim é, além 
da possibilidade de nós próprios sermos transgénicos, não conseguimos perceber que o mundo de consumo onde nos movimentamos está, também, repleto de objectos transgénicos que estão à nossa disposição. Consumimos refrigerantes, cereais, sopas, óleos, alimentos enlatados, biscoitos modificados em laboratório, sem, contudo, reflectir nas suas implicações no mundo contemporâneo. E O Oitavo Dia dramatiza essa circunstância levando-nos a pensá-la de forma séria. Quando Kac cria os seres transgénicos e os insere num ambiente de convívio com os humanos, propõe-nos que analisemos esses animais não humanos como um "outro", seres com os quais estabelecemos relações de ética e responsabilidade.

Desta forma, Kac pensa o tradicional conceito de responsabilidade sobre o animal como elemento chave da relação entre as entidades (Silva, 2007). Quando se criam novas vidas transgénicas, é preciso pensar o sentimento de responsabilidade que temos para com o outro. Como propõe Jacques Derrida (2002), é preciso olhar o outro, o animal não-humano, com responsabilidade pessoal, ou seja, o cuidado que temos com este e as possibilidades que ele tem de se manifestar enquanto outro. A esta proposição de Derrida, podemos acrescentar ainda o pensamento de Emmanuel Lévinas, para quem o rosto revela um outro que exige respeito. Assim, a relação face-a-face entre o "eu" e o "outro" estabelece a proximidade, cujo sentido primordial e último, para Lévinas, é a responsabilidade do eu pelo outro sem que, contudo, seja necessária a ocorrência da reciprocidade, porque, se houvesse essa exigência, tratar-se-ia apenas de uma relação desinteressada (Lévinas, 2000).

Tal como diz Kac a respeito das suas criações: "No momento em que esse ser está em sua frente e te olha nos olhos é impossivel não levar em consideração a responsabilidade que você passa a ter." (Machado, 2002).

Segundo Lévinas, reconhecer a diferença não significa incorporar a indiferença. Pelo contrário, trata-se de assumir a responsabilidade por esse outro. Aí reside a ética da autoridade: dar abertura a esse outro que se revela outro pela bioluminescência, para reflectir a comunicação entre o ser humano e o ser transgénico (Silva, 2007). Desta forma, o projecto artístico reflecte o poder e a tecnologia, a ética e a estética, questionando todo o tipo de heranças imutáveis. Como diz Silva (2007), o resultado do projecto é a plenitude de possibilidades interpretativas, na medida em que o ecossistema transgénico se configura numa espécie de resposta da natureza à pretensiosa sabedoria por parte do ser humano, que se designa como o dono de todas as formas vivas do Universo. Assim, esta combinação da arte com a engenharia genética não 
fomenta a criação de criaturas vivas modificadas em laboratório com vista à reprodução e manipulação desses seres. Pelo contrário, o artista propõe uma reflexão mais profunda sobre os desenvolvimentos artístico-científicos, discutindo questões de ética e de responsabilidade. "A sua meta" - conclui Arlindo Machado (2000) - "é sempre a dimensão simbólica da genética e não a sua dimensão simplesmente operacional".

Desta forma, como afirma Luís Quintais (2007: 93):

"O que Kac vem realizar é uma arte que se define tendo por medida o apuro do presente, fazendo-nos conviver com um mundo que exige problematização e reconstrução. Esta reconstrução é imperiosa porque a deriva biotecnológica é seguramente inescapável e, provavelmente, imparável."

O Oitavo Dia constitui-se então como uma chamada de atenção para o diálogo sobre a ética e a responsabilidade na relação entre todos os seres (humanos, plantas, animais, ...) que co-habitam o mesmo espaço.

Foi assim objectivo deste artigo reflectir e contribuir dentro do possível para uma maior elucidação destes fenómenos, esperando que através da sua compreensão algumas das problemáticas abordadas possam ser desmistificadas, dando origem a uma perspectiva mais optimista do que catastrofista sobre os recentes avanços que diariamente nos espantam e nos fazem admirar as potencialidades de criação do ser humano.

\section{Referências bibliográficas:}

Beiguelman, G. 2001. A coelhinha e a bioarte: Eduardo Kac discute ética e afeto no mundo dos seres criados em laboratório. Trópico [Online]. Rio de Janeiro, Kac. [Consultado em 11-2-2010]. Disponível em: http://www.ekac.org/ beiguelmanweb.html.

Beiguelman, G. 2002. Kac questiona o natural e o artificial em toda a sua obra. Folha de São Paulo. [Online]. Rio de Janeiro, Kac. [Consultado em 11-22010]. Disponível em: http://www.ekac.org/gisfolha2002.html.

Collins, D. 2003. Tracking chimeras: the eighth day of Eduardo Kac. [Online]. Tempe, Collins "official" School of Art Page. [Consultado em 2-11-2010]. Disponível em: http://www.asu.edu/cfa/art/people/faculty/collins/Kac/. 
Cruz, N. V. 2004. Comunicação, arte e ciência: as experiências de Eduardo Kac e Christa Sommerer \& Laurent Mignonneau. Tese de Doutorado em Comunicação [Online]. Rio de Janeiro, Escola de Comunicação da Universidade Federal do Rio de Janeiro. [Consultado em 11-2-2010]. Disponível em: http://www.dominiopublico.gov.br/pesquisa/DetalheObraForm.do?select_ action $=\&$ co_obra $=42406$.

Derrida, J. 2002. O animal que logo sou. São Paulo, Editora UNESP.

Kac, E. 2005. Telepresence \& Bio Art: networking humans, rabbits \& robots. Michigan, The University of Michigan Press.

Lévinas, E. 2000. Totalidade e infinito. Lisboa, Edições 70.

Machado, A. 2000. Por uma arte transgênica. [Online]. Rio de Janeiro, Kac. [Consultado em 11-2-2010]. Disponível em: http://www.ekac.org/arlimachtrans. html. [Tradução de: Machado, A. 2000. Por un arte transgenico. In: Perla, J. (ed.) De la pantalla al arte transgenico. Buenos Aires, Libros de Rojas: 253-260].

Machado, C. 2002. Estética transgênica. Folha de São Paulo. [Online]. Rio de Janeiro, Kac. [Consultado em 11-2-2010]. Disponível em: http://www.ekac. org/cassiano.html.

Philipkoski, K. 2002. RIP: Alba, the glowing bunny. [Online]. Wired.com., Condé Nast Digital. [Consultado em 11-2-2010]. Disponível em: http://www.wired. com/news/medtech/1,54399-1.html.

Pisaneschi, J. 2006. BioArte: arte, ciência e tecnologia. [Online]. Especialização em Mídias Interativas, Centro Universitário Senac. [Consultado em 11-2-2010]. Disponível em: http://docs.thinkfree.com/tools/download. php? mode=down\&dsn=299914.

Punt, M. 2003. Nem ciência nem história: arte pós-biológica e seus primos distantes. In: Maciel, K., Parente, A. (eds.) Redes sensoriais: arte, ciência, tecnologia. Rio de Janeiro, Contra Capa Livraria: 309-317.

Quintais, L. 2007. Fluidez tectónica: as bio-tecno-ciências, a bio-arte e a paisagem cognitiva do presente. Revista Crítica de Ciências Sociais, 79: 79-94.

Silva, K. F. 2007. Arte transgênica: forma de comunicação entre os sujeitos. Revista Digital Art\& [Online], 5(7). [Consultado em 11-2-2010]. Disponível em: http://revista.art.br/site-numero-07/trabalhos/8.htm.

Artigo recebido a 22 de Fevereiro de 2010 e aceite a 13 de Abril de 2010. 